\title{
Regenerative medicine in China: demands, capacity, and regulation
}

Biao Cheng ${ }^{1,2}$, Shuliang $\mathrm{Lu}^{3}$ and Xiaobing $\mathrm{Fu}^{1,4^{*}}$

\begin{abstract}
Regenerative medicine (RM) is an emerging interdisciplinary field of research. Its clinical application focuses on the repair, replacement, and regeneration of cells, tissues, and organs by approaches including cell reprogramming, stem cell transplantation, tissue engineering, activating factors, and clone treatment. RM has become a hot point of research in China and other countries. China's main and local governments have attached great importance to RM and given strong support in relevant policies and funding. About 3.5 billion RMB has been invested in this field. Since 1999, China has established about 30 RM centers and cooperates with many advanced countries in RM research and benefits from their cooperation. However, China needs to develop standards, regulations, and management practices suitable for the healthy development of RM. In this review, we focus on its great demand, capacity, and relative regulations.
\end{abstract}

Keywords: Regenerative medicine, Stem cell, Tissue engineering, China

\section{Background}

Annually, about 100 million Chinese patients will receive treatment by tissue repair and regeneration technologies because of the sharp increase in various injuries, accidents, and diseases of aging. However, the current paradigm of "healing by scar tissue replacement," regardless of superficial tissues or visceral organs, is stagnating and is far away from the ultimate goal of "regenerating the impaired organ." Regenerative medicine (RM) is gradually being used to restore the intrinsic repair ability with stem cell transplantation, tissue engineering, activating factors, cell reprogramming, and genetic treatments. RM holds sound promise of restoring organ function that is impaired because of congenital disorders, acquired disease, trauma, and aging by replacing or regenerating cells, tissues, and even organs. RM is expected to transcend traditional organ transplantation and replacement. Stem cell technology and tissue engineering have an outstanding role in RM. RM will become one of the most promising areas of life science in the twenty-first century $[1,2]$.

\footnotetext{
* Correspondence: fuxiaobing@vip.sina.com

${ }^{1}$ College of Life Sciences, Medical College of PLA, General Hospital of PLA, Beijing 100853, People's Republic of China

${ }^{4}$ Chinese Academy of Engineering (Division of Medical and Health), College of Life Sciences, Medical College of PLA, General Hospital of PLA, 28 Fu Xian Road, Beijing 100853, People's Republic of China

Full list of author information is available at the end of the article
}

In the past 20 years, the RM market has continued to grow in China and other countries such as the USA, Europe, Japan, and Singapore. As the largest developing country, China has impressed the world with its findings in stem cells, tissue engineering, active molecules, and gene therapy as well as its national strategies and regulation of RM. These achievements may benefit China in both disease treatment and society development [3].

\section{Review \\ Strategies, guidance, funding, and industrialization of RM in china \\ National strategies}

The central government of China supports the development of RM. In the 2006 National Plan for Long-and Medium-Term Scientific and Technological Development (2006-2020), stem cells and RM technologies were the important fields among the five biotechnologies (http:// www.gov.cn/gzdt/2009-08/21/content_1398305.htm). Also, local governments have adopted stem cell research as one of the priorities of technological development and provided active support. Relevant government departments and academia have paid close attention to and encouraged the development of RM. In the Science \& Technology on Public Health in China: A Roadmap to 2050, issued by the 
Table 1 Management specification of stem cell transplantation techniques

\begin{tabular}{l}
\hline Time Management specification of stem cell transplantation techniques \\
\hline 2006 Unrelated Hematopoietic Stem Cell Transplantation Technique \\
Unrelated Hematopoietic Stem Cell Transplantation Collection \\
Technique \\
2009 Cord Blood Stem Cell Therapy Technology (Trial) \\
Tissue-engineering Tissue Transplantation Therapy Technique (Trial)
\end{tabular}

Chinese Academy of Sciences (CAS) [4], and the Study on the Long- and Medium-Term Development Strategy for China Engineering Science and Technology, issued by the Chinese Academy of Engineering (CAE) (http://news. sciencenet.cn/htmlnews/2012/12/273300-3.shtm), RM was considered a major research field. In the Roadmap of Translational Medicine in China issued by CAE, RM and biotherapy are main fields. Industrialization of RM is a part of the "12th Five-Year Planning" and will be nurtured as a source of economic growth.

The strategic science and technology projects from CAS can be divided into "Forward-Looking Strategic Priority Research Program of Science and Technology" and "Construction of Research Centers for Basic and Forefront Scientific Research." Academia held three Xiangshan Science Conferences on RM, in 2005, 2010, and 2015, to discuss the philosophy, scope, and major breakthroughs needed for the development of RM in China and the key scientific issues to be addressed. In addition, the Xiangshan Science Conference organized seminars on stem cell biology and cloning, strategies for research and development of gene therapy and biomaterials, and tissue engineering.

\section{Regulatory and scientific guidance}

Policies and regulations reflect that China is gradually strengthening the management of RM research and clinical application. Since 1999, when the Ministry of Health (MH) promulgated the first Umbilical cord blood stem cell bank management approach (Trial), about 30 rules and regulations have been issued by the Ministry of Science and Technology (MST), the MH, and the State Food and Drug Agency (SFDA) (Table 1).

In 2011, the First National Stem Cell Research Guidance and Coordination Committee was established for the overall design and scientific planning of stem cell research

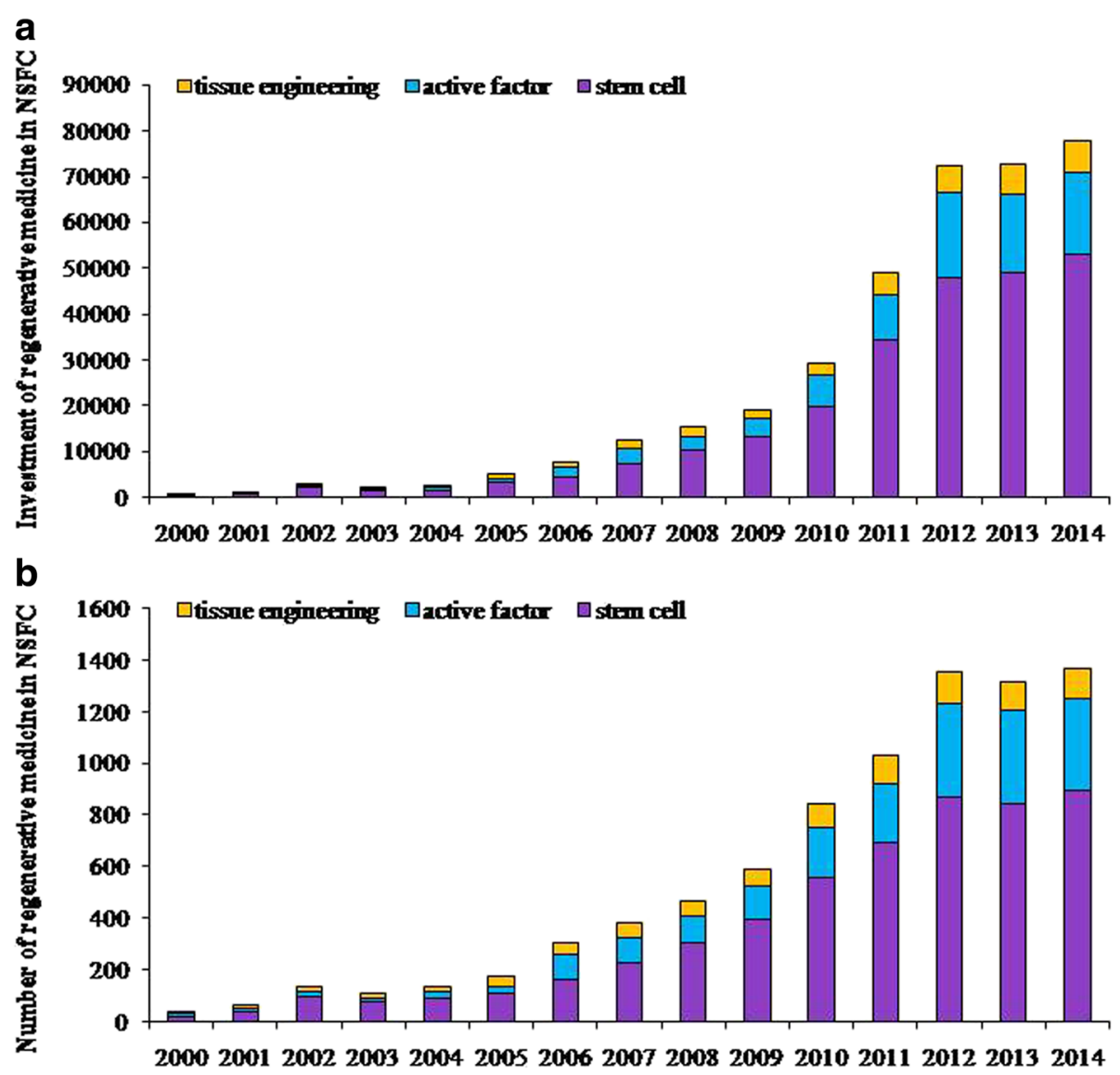

Fig. 1 National Natural Science Foundation of China investment in regenerative medicine from 2000 to 2014. a Amount of funding. $\mathbf{b}$ Number of funds 
in China. In December 2011, the Notice on Carrying out Self-inspection and Self-rectification Campaign Regarding Stem Cell Clinical Research and Application was issued. In 2013, the stem cell clinical research and application rectification lead group of the MH and SFDA formulated the regulations Management Specification of Stem Cell Clinical Trials (Trial), Management Specification of Stem Cell Clinical Trial Research Base (Trial), and Stem Cell Preparation Quality Control and Pre-clinical Research Guidelines (Trial). These regulations will be implemented soon and help in the development of RM in China. In 2015, China MH opens the window to allow the stem cell clinic trial and stem cell research bases which will promote the development of stem cell research and translational application in China.

\section{Funding support and resources}

Multiple sources are funding RM studies and translational application. After 1999, the MST approved the National Program on Key Basic Research Project (973 Program) related to tissue engineering, and the stem cell field had the largest number of "973 Program" projects. Research into the clinical transformation and application of stem cell therapy was established in the biotechnology and medical technology field of the "863 Program." The National Natural Science Foundation (NNSF) funded about 200 million RMB for this study, including 5627 items (Fig. 1a, b). Up to now, about 3 billion RMB from the MST, CAS, and NNSF has been invested in this field. Both the amount of funding and number of projects are increasing annually. Other funding for RM from companies is about

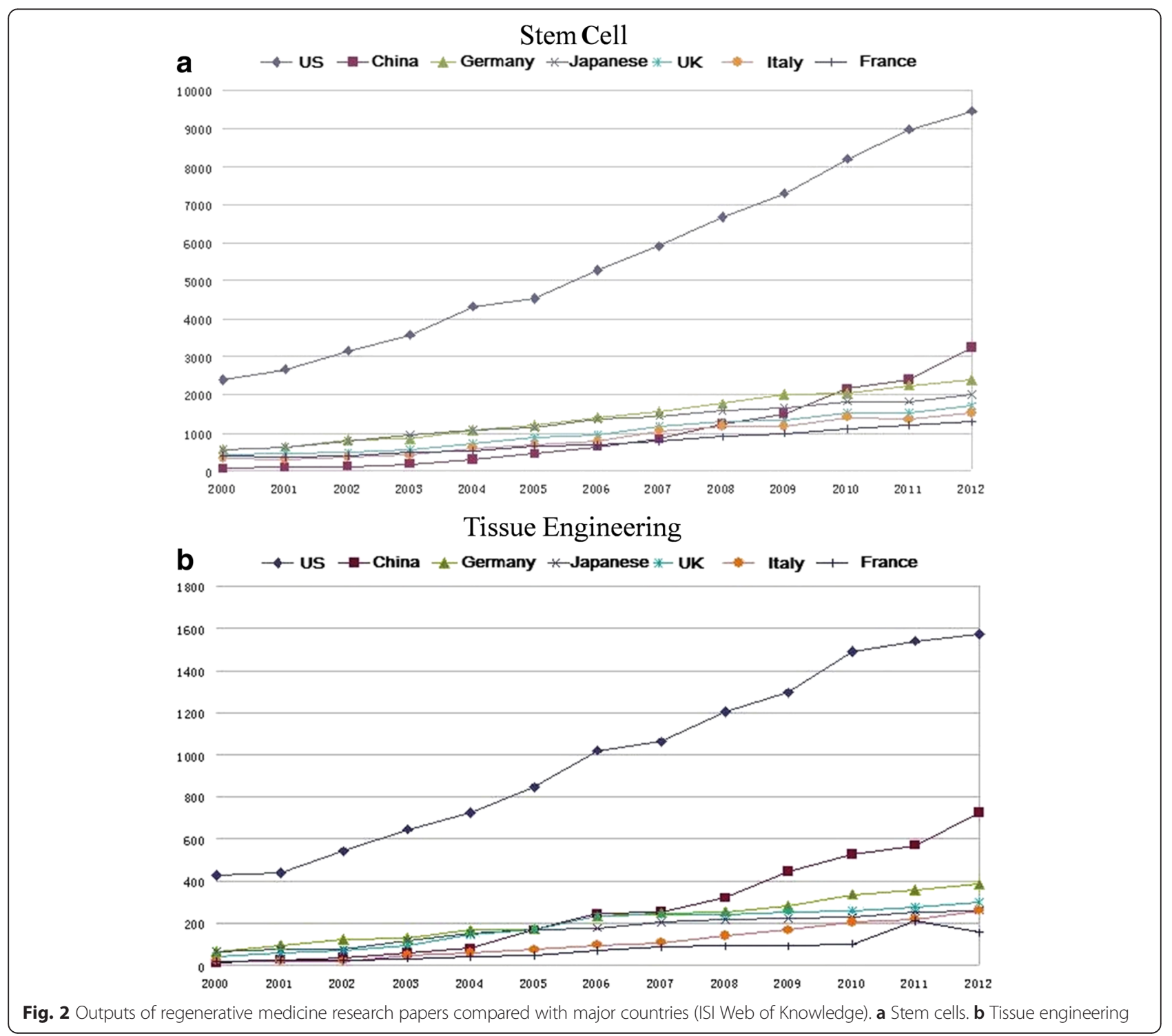


Table 2 Main monographs on regenerative medicine published in China

\begin{tabular}{|c|c|c|c|}
\hline Time & Name & Author & Publishing company \\
\hline 2008.03 & $\begin{array}{l}\text { Regenerative Medicine: From Basic to Clinic } \\
\text { Research }\end{array}$ & $\begin{array}{l}\text { Fu Xiaobing, Wang Zhengguo, } \\
\text { Wu Zuze [5] }\end{array}$ & Shanghai Scientific and Technical Publishers \\
\hline 2010.05 & Regenerative Medicine: Theory and Technology & Pei Xuetao [6] & Science Press \\
\hline 2012.03 & Regenerative Medicine & Ding Fei, Liu Wei, Gu Xiaosong [7] & People's Medical Publishing House \\
\hline 2013.08 & Regenerative Medicine: Basic and Clinical Research & $\begin{array}{l}\text { Fu Xiaobing, Wang Zhengguo, } \\
\text { Wu Zuze [8] }\end{array}$ & People's Medical Publishing House \\
\hline 2014.10 & Tissue Engineering and Regenerative Medicine & Jin yan [9] & People's Medical Publishing House \\
\hline 2015.03 & $\begin{array}{l}\text { Chinese Discipline Development Strategy } \\
\text { Regenerative Medicine }\end{array}$ & Chinese Academy of Sciences [10] & Science Press \\
\hline
\end{tabular}

Table 3 Main monographs on stem cells published in China

\begin{tabular}{|c|c|c|c|}
\hline Time & Name & Author & Publishing company \\
\hline 1988.01 & Basic Hematopoietic Stem Cell Transplant & Wu Zuze [11] & People's Medical Publishing House \\
\hline 2000.04 & Stem Cells and Developmental Biology & $\begin{array}{l}\text { Ye Xinsheng, Xu Tian, Tang Xifang, } \\
\text { Pei Xuetao [12] }\end{array}$ & Military Medical Science Press \\
\hline 2000.09 & Peripheral Blood Stem Cell Transplantation & Da Wanming, Pei Xuetao [13] & People's Medical Publishing House \\
\hline 2000.11 & $\begin{array}{l}\text { Hematopoietic Stem Cells Theory and } \\
\text { Transplant Technique }\end{array}$ & Han Zhongchao [14] & Henan Science and Technology Press \\
\hline 2003.07 & Stem Cell Biology & Pei Xuetao [15] & Science Press \\
\hline 2005.03 & Stem Cells Theory and Technique & Wang Tinghua, Li Liyan [16] & Science Press \\
\hline 2005.05 & Stem Cells Biology & Hu Huozhen [17] & Sichuan University Press \\
\hline 2006.05 & Principles, Technology and Clinic of Stem Cell & Zhao Chunhua [18] & Chemical Industry Press \\
\hline 2006.07 & Neural Stem Cell Foundation and Application & Zhu Xiaofeng [19] & Science Press \\
\hline 2006.12 & Neural Stem Cell & Xu Ruxiang [20] & Military Medical Science Press \\
\hline 2007.03 & $\begin{array}{l}\text { Hematopoietic Stem Cell Biology and } \\
\text { Research Methods }\end{array}$ & Wang Yaping [21] & Science Press \\
\hline 2007.07 & Stem Cell Aging and Disease & Wang Yaping [22] & Science Press \\
\hline 2008.02 & Fundamental and Clinic Research of Stem Cells & Yu Yue [23] & $\begin{array}{l}\text { Press of University of Science and } \\
\text { Technology of China }\end{array}$ \\
\hline 2010.07 & New Technologies of Stem cell Application & Yang Xiaofeng, Zhang Sufen, Guo Zikuan [24] & Military Medical Science Press \\
\hline 2010.01 & Clinical Research of Mesenchymal Stem Cells & Wang Tong [25] & People's Medical Publishing House Co., Ltd \\
\hline 2011.08 & $\begin{array}{l}\text { The Basis, Ethics and Principles of Clinical } \\
\text { Applications of Stem Cells }\end{array}$ & Jin Kunlin [26] & Science Press \\
\hline 2011.12 & $\begin{array}{l}\text { Research Legal Regulation of Human Embryonic } \\
\text { Stem Cell }\end{array}$ & Zhao Xu [27] & Shanghai People's Publishing House \\
\hline 2012.04 & $\begin{array}{l}\text { Mesenchymal Stem Cells: Basic Research and } \\
\text { Clinical Application }\end{array}$ & Han Zhongchao [28] & Science Press \\
\hline 2012.10 & Clinical Research and Application of Stem Cells & $\begin{array}{l}\text { Gu Yongquan, Han Zhongcao, } \\
\text { Fu Xiaobing [29] }\end{array}$ & People's Medical Publishing House \\
\hline 2012.10 & $\begin{array}{l}\text { Application of Stem Cell Technology for } \\
\text { Cardiovascular Diseases }\end{array}$ & Ma Yitong, Ge Junbo [30] & People's Medical Publishing House \\
\hline 2012.06 & $\begin{array}{l}\text { Development Report on Technology and } \\
\text { Industry of Stem Cell }\end{array}$ & $\begin{array}{l}\text { Dai Tao, Chi Hui, Fu Xiaobing, Pei Xuetao, } \\
\text { Zhou Qi, Li Defu, Lan Baoshi [31] }\end{array}$ & Science Press \\
\hline 2014.06 & $\begin{array}{l}\text { Practice of Hematopoietic Stem Cell } \\
\text { Transplantation }\end{array}$ & Huang Xiaojun [32] & People's Medical Publishing House \\
\hline 2014.07 & Clinical Progress of Stem Cell Therapy & Han Zhongchao [33] & $\begin{array}{l}\text { Tianjin Science and Technology } \\
\text { Translation Publishing Co., Ltd }\end{array}$ \\
\hline
\end{tabular}


500 million RMB. In 2015, NNSF plans to invest RM research as its "Great Research Plan," and MST has issued its new scientific research grand with about 21 billion RMB in RM field.

\section{Translating outcomes into industrialization}

The establishment of centers and technological translational application are important for RM development. Since 1999, China has established about 30 RM centers. These centers are involved in stem cell research and its translational application (e.g., national stem cell east center and national stem cell centers in Tianjin, Qingdao, Wuxi, Taizhou, etc.) (http://www.bioon.com/biology/cell/ 28500.shtml); national stem cell and RM technology innovation strategic alliance (sponsors and governing members include 27 first-class research institutes, wellknown three-A hospitals, several "211 Project" key universities and industry leaders); and a tissue engineering innovation center in Shanghai. In 2011, the first academic workstation for the industrialization of stem cell technology was launched in the Inner Mongolia Autonomous Region. Companies such as Cyagen Biosciences (Guangzhou) and Hangzhou Biowish Technology (Biowish) are specialized in the development and sales of stem cell products. In 2009, NeoStem announced that it had reached an exclusive agreement for strengthening biomedical cooperation with Shanghai enterprises. This agreement aims to establish a network of stem cell collection and treatment centers in Shanghai, Jiangsu, Zhejiang, Fujian, Anhui, and Jiangxi provinces. In 2010, the Beike Stem Cell Bank and Stem Cell Preparation Laboratory successfully passed the ISO 9001 quality management system certification and obtained the qualification certification issued by China Quality Certification Center, becoming the first comprehensive stem cell bank to pass ISO 9001 quality management system certification in China (http:// www.bioon.com/industry/enterprisenews/432100.shtml).

\section{Production in academic fields}

Publication of valued scientific papers is one of the very important indicators to evaluate investment and production in academic fields. The total number of scientific papers dealing with RM has increased quickly in China, as has the number published in leading scientific journals in China and internationally (Fig. 2). Since the 1960s, the USA has published 599 articles about stem cells in Cell and its subjournals (36), Germany published 45, Japan 36, and China only 17. Since 2000 , the number of annual patent applications for stem cells has increased quickly and amounted to 1333 in 2009. In 2011, the Chinese literature related to stem cells outnumbered that of published by German, Japanese, and UK researchers and ranked second. In 2012, it had increased. In terms of citations, the USA ranked the first, with a mean of 32.2 citations per item. However, citations for Chinese publications are increasing annually, and the mean number is currently 10.19. For patent applications, as of March 2010, the number of China stem cell-related patent applications and patent applications as a patent priority country was ranked the sixth and third in the world, respectively. The USA, Japan, and China have applied for more patents as patent priority countries (http://www.chinainfo.gov.cn/Report/ArticlesView.aspx?aid=7924).

Also, many monographs on stem cells or tissue engineering and RM have been published which play some role in pushing the research of RM in China (Tables 2, 3, and 4).

Table 4 Main monographs of tissue engineering published in China

\begin{tabular}{|c|c|c|c|}
\hline Time & Name & Author & $\begin{array}{l}\text { Publishing } \\
\text { Company }\end{array}$ \\
\hline 2002.09 & Tissue Engineering & $\begin{array}{l}\text { Yang } \\
\text { Zhiming [34] }\end{array}$ & $\begin{array}{l}\text { Chemical Industry } \\
\text { Press }\end{array}$ \\
\hline 2003.08 & $\begin{array}{l}\text { Repair of Medicine and } \\
\text { Tissue Engineering }\end{array}$ & Lao Weide [35] & $\begin{array}{l}\text { Chemical Industry } \\
\text { Press }\end{array}$ \\
\hline 2004.06 & $\begin{array}{l}\text { Principles and Protocol } \\
\text { of Tissue Engineering }\end{array}$ & Jin Yan [36] & $\begin{array}{l}\text { Fourth Military } \\
\text { Medical University } \\
\text { Press }\end{array}$ \\
\hline 2004.12 & $\begin{array}{l}\text { The Theory and Practice } \\
\text { of Tissue Engineering }\end{array}$ & Cao Yilin [37] & $\begin{array}{l}\text { Shanghai } \\
\text { Scientific } \\
\text { and Technical } \\
\text { Publishers }\end{array}$ \\
\hline 2005.06 & $\begin{array}{l}\text { Basic and Clinic Research } \\
\text { on Tissue Engineering }\end{array}$ & $\begin{array}{l}\text { Yang } \\
\text { Zhiming [38] }\end{array}$ & $\begin{array}{l}\text { Sichuan Scientific } \\
\text { and Technological } \\
\text { Press }\end{array}$ \\
\hline 2006.05 & $\begin{array}{l}\text { Tissue Engineering: A } \\
\text { Laboratory Manual }\end{array}$ & $\begin{array}{l}\text { Pei Guoxian, Wei } \\
\text { Kuanhai, Jin } \\
\text { Dan [39] }\end{array}$ & $\begin{array}{l}\text { Military Medical } \\
\text { Science Press }\end{array}$ \\
\hline 2008.01 & Tissue Engineering & Cao Yilin [40] & Science Press \\
\hline 2009.05 & $\begin{array}{l}\text { Tissue Engineering } \\
\text { of Skin }\end{array}$ & $\begin{array}{l}\text { Wu Jinjin, } \\
\text { ZhuYoutang [41] }\end{array}$ & $\begin{array}{l}\text { Military Medical } \\
\text { Science Press }\end{array}$ \\
\hline 2010.02 & $\begin{array}{l}\text { Biomaterials and } \\
\text { Tissue Engineering }\end{array}$ & $\begin{array}{l}\text { Xiong } \\
\text { Dangsheng [42] }\end{array}$ & Science Press \\
\hline 2011.03 & $\begin{array}{l}\text { Stem Cell Tissue } \\
\text { Engineering: Basic } \\
\text { Theory and Clinical } \\
\text { Application }\end{array}$ & $\begin{array}{l}\text { Wang } \\
\text { Dianliang [43] }\end{array}$ & Science Press \\
\hline 2012.01 & $\begin{array}{l}\text { Introduction to Human } \\
\text { Tissue Engineering }\end{array}$ & $\begin{array}{l}\text { Guan Guangju, } \\
\text { Jiang Duyin [44] }\end{array}$ & $\begin{array}{l}\text { Shandong } \\
\text { University Press }\end{array}$ \\
\hline 2015.01 & $\begin{array}{l}\text { Fabrication and Structure } \\
\text { Performance of } \\
\text { Biodegradable Tissue } \\
\text { Engineering Scaffolds }\end{array}$ & $\begin{array}{l}\text { Cui } \\
\text { Zhixiang [45] }\end{array}$ & $\begin{array}{l}\text { National Defence } \\
\text { Industry Press }\end{array}$ \\
\hline 2015.06 & $\begin{array}{l}\text { Medical Polysaccharide } \\
\text { Material }\end{array}$ & $\begin{array}{l}\text { Dan } \\
\text { Huaping [46] }\end{array}$ & Science Press \\
\hline
\end{tabular}




\section{International collaboration and opportunities for RM in China}

Open and cooperative regulations are basic in China. Since 2005, China has cooperated with many countries that are advanced in RM at different levels. Six world-renowned comprehensive RM research institutions from Germany, the USA, Canada, Spain, and The Netherlands established a Regenerative Medicine Coalition (RMC) to jointly promote the research and innovation of RM therapy at cellular levels (Table 5). Even some large foreign pharmaceutical companies, such as General Electric and Sanofi-Aventis, have invested in China for stem cell-related research and achieved relevant results (http://lib.cet.com.cn/paper/ szb_con.aspx?id=140472) $[47,48]$. Also, the use of theories and skills of RM in military medicine is one of the important fields in the future [49].

Table 5 Collaborations between China and other countries in regenerative medicine research

\begin{tabular}{|c|c|c|}
\hline $\begin{array}{l}\text { Country of } \\
\text { collaboration }\end{array}$ & Time & Objects \\
\hline \multirow[t]{2}{*}{ France } & 2005 & $\begin{array}{l}\text { Institute of Zoology (IOZ), Chinese Academy } \\
\text { of Sciences, and the French National Institute } \\
\text { for Agricultural Research }\end{array}$ \\
\hline & 2007 & $\begin{array}{l}\text { The Chinese-French Joint Laboratory of } \\
\text { Biology of Embryonic Cells of Mammals }\end{array}$ \\
\hline Australia & 2007 & $\begin{array}{l}\text { Sino-Australia Center of Excellence for Stem } \\
\text { Cell Science }\end{array}$ \\
\hline \multirow[t]{2}{*}{ Canada } & 2007 & $\begin{array}{l}\text { Monash Immunology and Stem } \\
\text { Cell Laboratories (MISCL) was awarded a } \\
\text { federal government grant to establish a } \\
\text { joint Australia-China Centre for Excellence } \\
\text { in Stem Cell Science with Peking University. }\end{array}$ \\
\hline & 2009 & $\begin{array}{l}\text { The Ministry of Science and Technology and } \\
\text { the Canadian Institutes of Health Research } \\
\text { signed a memorandum of understanding. }\end{array}$ \\
\hline \multirow[t]{3}{*}{ UK } & 2005 & $\begin{array}{l}\text { The Committee of the National Natural } \\
\text { Science Foundation of China and the UK } \\
\text { Medical Research Council signed a } \\
\text { memorandum of cooperation. }\end{array}$ \\
\hline & 2009 & $\begin{array}{l}\text { Scottish Centre for Regenerative Medicine } \\
\text { (SCRM) and Peking University Stem Cell } \\
\text { Research Center (PKUSCRC) established a } \\
\text { national international joint research center. }\end{array}$ \\
\hline & 2012 & $\begin{array}{l}\text { UK Medical Research Council and the National } \\
\text { Natural Science Fund Committee cooperated } \\
\text { to jointly fund a stem cell research project. }\end{array}$ \\
\hline USA & 2009 & $\begin{array}{l}\text { The California Institute for Regenerative } \\
\text { Medicine (CIRM) and the Chinese Ministry } \\
\text { of Science and Technology (MST) signed } \\
\text { an agreement to collaborate on stem cell } \\
\text { research. }\end{array}$ \\
\hline Germany & 2009 & $\begin{array}{l}\text { The National Natural Science Fund Committee } \\
\text { and the German Science Foundation } \\
\text { cooperated to jointly fund a stem cell } \\
\text { research project. }\end{array}$ \\
\hline
\end{tabular}

\section{Conclusions}

Great demands in RM are not only in China but also in the world. Their theories and key skills or products are used not only in peacetime but also in military field [49]. The Chinese government attaches great importance to this field, and vigorous investments from the government and companies may accelerate the progress in basic research and translational application. Innovation and international cooperation will be emphasized in future studies. Other sound administrative system, laws, technical specifications, and guidelines are very important in pushing their healthy and orderly development.

\section{Acknowledgements}

This study was supported in part by the National Nature Science Foundation of China $(81121004,81230041,81171812,81272105$, and 81171798) and the National Basic Science and Development Programme (973 Program, 2012CB518105) and National Science and Technology Major Project (2011ZXJ07104B-03B)

\section{Authors' contributions}

BC and XF conceived and designed the project, collected and analyzed the data, and participated in the writing process. SL participated in data collection. All authors read and approved the final manuscript.

\section{Competing interests}

The authors declare that they have no competing interests.

\section{Author details}

${ }^{1}$ College of Life Sciences, Medical College of PLA, General Hospital of PLA, Beijing 100853, People's Republic of China. ${ }^{2}$ The Key Laboratory of Trauma Treatment \& Tissue Repair of Tropical Area, PLA, Guangzhou 510010, People's Republic of China. ${ }^{3}$ Ruijin Hospital, Shanghai Jiao Tong University, Shanghai 200025, People's Republic of China. ${ }^{4}$ Chinese Academy of Engineering (Division of Medical and Health), College of Life Sciences, Medical College of PLA, General Hospital of PLA, 28 Fu Xian Road, Beijing 100853, People's Republic of China.

Received: 23 March 2016 Accepted: 27 April 2016

Published online: 02 June 2016

\section{References}

1. Nerem RM. Regenerative medicine: the emergence of an industry. J R Soc Interface. 2010;7(Suppl 6):S771-S775.

2. Stoltz JF, Isla N, Li YP, Bensoussan D, Zhang L, Huselstein C, et al. Stem Cells and Regenerative Medicine: Myth or Reality of the 21th Century. Stem Cells Int. 2015;2015:734731.

3. Fu X. Regenerative medicine research in China: from basic research to clinical practice. Science China Life Sciences. 2014;57(2):155-6.

4. Chen K, Lin Q, Wu J. Science \& Technology on Public Health in China: A Roadmap to 2050. Berlin, Heidelberg; Springer Berlin Heidelberg; 2010.

5. Fu X, Wang Z, Wu Z. Regenerative medicine: from basic to clinic research. Shanghai: Shanghai Scientific \& Technical Publishers; 2008.

6. Pei X. Regenerative medicine: theory and technology. Beijing: Science Press; 2010.

7. Ding F, Liu W, Gu X. Regenerative medicine. Beijing: People's Medical Publishing House; 2012.

8. Fu X, Wang Z, Wu Z. Regenerative medicine: basic and clinical research. Beijing: People's Medical Publishing House; 2013.

9. Jin Y. Tissue engineering and regenerative medicine. Beijing: People's Medical Publishing House; 2014.

10. Chinese Academy of Sciences. Chinese discipline development strategy regenerative medicine. Beijing: Science Press; 2015.

11. Wu Z. Basic hematopoietic stem cell transplant. Beijing: People's Medical Publishing House; 1988.

12. Ye X, Xu T, Tang X, Pei X. Stem cells and developmental biology. Beijing: Military Medical Science Press; 2000.

13. Da W. Pei X. Peripheral blood stem cell transplantation. Beijing: People's Medical Publishing House; 2000. 
14. Han Z. Hematopoietic stem cells theory and transplant technique. Zhengzhou: Henan Science and Technology Press; 2000.

15. Pei X. Stem cell biology. Beijing: Science Press; 2003.

16. Wang T, Li L. Stem cells theory and technique. Beijing: Science Press; 2005.

17. Hu H. Stem cells biology. Chengdu: Sichuan University Press; 2005.

18. Zhao C. Principles, technology and clinic of stem cell. Beijing: Chemical Industry Press; 2006.

19. Zhu X. Neural stem cell foundation and application. Beijing: Science Press; 2006.

20. Xu R. Neural stem cell. Beijing: Military Medical Science Press; 2006.

21. Wang Y. Hematopoietic stem cell biology and research methods. Beijing: Science Press; 2007.

22. Wang Y. Stem cell aging and disease. Beijing: Science Press. 2007.

23. Yu Y. Fundamental and clinic research of stem cells. Hefei: Press of University of Science and Technology of China; 2008.

24. Yang X, Zhang S, Guo Z. New technologies of stem cell application. Beijing: Military Medical Science Press; 2010.

25. Wang T. Clinical research of mesenchymal stem cells. Beijing: People's Medical Publishing House Co.,Ltd; 2010.

26. Jin K. The basis, ethics and principles of clinical applications of stem cells. Beijing: Science Press; 2011.

27. Zhao X. Research legal regulation of human embryonic stem cell. Shanghai: Shanghai People's Publishing House; 2011.

28. Han Z. Mesenchymal stem cells: basic research and clinical application. Beijing: Science Press; 2012

29. Gu Y, Han Z, Fu X. Clinical research and application of stem cells. Beijing: People's Medical Publishing House; 2012.

30. Ma Y, Ge J. Application of stem cell technology for cardiovascular diseases Beijing: People's Medical Publishing House; 2012.

31. Dai T, Chi H, Fu X, Pei X, Zhou Q, Li D, Lan B. Development report on technology and industry of stem cell. Beijing: Science Press; 2012

32. Huang X. Practice of hematopoietic stem cell transplantation. Beijing: People's Medical Publishing House; 2014.

33. Han Z. Clinical progress of stem cell therapy. Tianjin: Tianjin Science and Technology Translation Publishing Co., Ltd; 2014.

34. Yang Z. Tissue engineering. Beijing: Chemical Industry Press; 2002.

35. Lao W. Repair of medicine and tissue engineering. Beijing: Chemical Industry Press; 2003.

36. Jin Y. Principles and protocol of tissue engineering. Xi'an: Fourth Military Medical University Press; 2004.

37. Cao Y. The theory and practice of tissue engineering. Shanghai: Shanghai Scientific \& Technical Publishers; 2004.

38. Yang Z. Basic and clinic research on tissue engineering. Chengdu: Sichuan Scientific and Technological Press; 2005.

39. Pei G, Wei K, Jin D. Tissue engineering: a laboratory manual. Beijing: Military Medical Science Press; 2006.

40. Cao Y. Tissue engineering. Beijing: Science Press; 2008.

41. Wu J, Zhu Y. Tissue engineering of skin. Beijing: Military Medical Science Press; 2009.

42. Xiong D. Biomaterials and tissue engineering. Beijing: Science Press; 2010.

43. Wang D. Stem cell tissue engineering: basic theory and clinical application. Beijing: Science Press; 2011

44. Guan $\mathrm{G}$, Jiang D. Introduction to human tissue engineering. Jinan: Shandong University Press; 2012.

45. Cui Z. Fabrication and structure performance of biodegradable tissue engineering scaffolds. Beijing: National Defence Industry Press; 2015.

46. Dan H. Medical polysaccharide material. Beijing: Science Press; 2015.

47. Cao N, Liu Z, Chen Z, Wang J, Chen T, Zhao X, et al. Ascorbic acid enhances the cardiac differentiation of induced pluripotent stem cells through promoting the proliferation of cardiac progenitor cells. Cell Res. 2012;22(1):219-36.

48. Fu X. Regenerative medicine research in China: from basic research to clinical practice. Science China Life Sciences. 2014; 57(2):155-6.

49. Fu X. Military medicine in china: old topic, new concept. Mil Med Res. 2014; $1: 2-5$.

\section{Submit your next manuscript to BioMed Central and we will help you at every step:}

- We accept pre-submission inquiries

- Our selector tool helps you to find the most relevant journal

- We provide round the clock customer support

- Convenient online submission

- Thorough peer review

- Inclusion in PubMed and all major indexing services

- Maximum visibility for your research

Submit your manuscript at www.biomedcentral.com/submit

) Biomed Central 